上述のように酸化した鉄表面の $\varepsilon_{h t}$ は表面酸化物の種類および厚 さによって，したがって酸化条件および酸化後の履歴によってこ となる。従来の測定は酸化条件が明確でないか，または条件が複 雑で表面酸化物の状態を推定しがたいものが多く, 值が広い範囲
にわたっているのはこれらの条件がことなるためであるう。

終りに本研究を行なうにあたって終始御想第な御指尊をいただ いた恩師京都大学名誉数授佐々木申二先生に厚く御礼申上げる。

\title{
放電した酸素で処理した白金表面からの原子状酸素の放出 ${ }^{11}$
}

\author{
(昭 和 35 年 7 月 6 日受理)
}

原納淑郎十

$0.1 \sim 1 \mathrm{mmHg}$ の王の放電した酸素ガスを白金リボンにあてて，後で真空中で $1400^{\circ} \mathrm{C} に$ 加熱したとてろ，白金表面から原子状 酸素が放出されるととを見いだした。しかし $1 \mathrm{mmHg}$ の酸素中で白金を加熱し，その後で真空中で高温に加熱しても原子状酸素 は検出されなかったので，白金表面に化学吸着した酸素原子は真空中で加熱すると分子状になって脱㴰すると考えられる。それゆ え前者の結果は白金表面に吸着した酸素原子が真空中で放出されるのではなく，白金表面に二酸化白金 $\left(\mathrm{PtO}_{2}\right)$ が生成されて後で 真空中で高温に加熱するときとの二酸化白金が分解して，原子状酸素を放出するものであると推論される。

\section{1 緒言}

放電した酸素の気流を白金リボンにあて，後で白金リボンを真 空中で高温に加熱すると原子状酸素が白金表面から放出される事 実を見いだしたのでここに報告する。

\section{2 酸素原子検出法}

原子状酸素を検出する方法につぎの三つが考えられる。

第一は淡黄色の一酸化鉛が褐色の過酸化鉛になる变化を利用し たものである。Kurt ら²が酸素の原子線の検出に用いているぐ らいであるから，相当鋭敏と思われるが，Kurt らは一酸化鉛を 酸水素焰で熱して昇華させ顕微鏡のカバーグラスに蒸着させてい る。そして，新たにつくって真空中に保存したものだけが活性に 富むというから，かなり面倒である。実際市販の一酸化鉛をその ままカバーグラスにつけてやってみたが，後述の酸化モリブデン による方法より不敏感であった。

第二は銀板による方法である。銀板はオゾンによって酸化され 過酸化銀 $\left(\mathrm{Ag}_{2} \mathrm{O}_{2}\right)$ を生じて黑変する。原子状酸素によっても同 様に黒変するであろうといわれている3。。オゾンの場合は銀板を あらかじめ金鋼砂でみがいておくと，鋭敏に変色するといわれて いる4)ので，われわれも銀板を金鋼砂でみがいて放電でつくった 酸素原子の流れにあててみた。 $4 \times 10^{-3} \sim 1 \mathrm{mmHg}$ の圧の範囲で 酸素を放電管に流して実験したところ，この圧範囲では恃の高い ほど，黒変の程度が大であった。しかし研究の主目的である白金 表面からの原子状酸素の放出のように, 酸素原子の搌度の小さい ときには銀板の処理の方法によって感度が大いに変化し，また酸 化モリブデンによる方法より不敏感であるので銀板は参考程度に 使用するにとどめた。

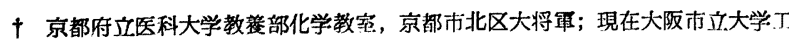
学部店用化学科, 大阪市北区南局町

1) K. Mitani, Y. Haranō, Bull. Chem. Soc. Japan 33, 276 (1960) 亿速報.

2) O. E. Kurt, T. E. Phipps, Phys. Rev. 34, 1357 (1929).

3) P. Harteck, U. Kopsch, Z. Elektrochem. 36, 714 (1930).

4) D. C. L. Thorne, E. R. Roberts, "Ephraim Inorganic Chemistry" 5th ed. p. 125 (1948).
最後に,三酸化モリブデンであるが, 感度が大でつくり方も容易 であるから，主としてこれによって酸素原子を検出した。三酸化 モリブデンは一辺 $18 \mathrm{~mm}$ の顕微鏡用カバーグラスに蒸着させた。 それには酸素原子検出装置に吊せるように，カバーグラスに絒い ガラス棒で吊り手をつけ，モリブデン線を入気中で電流により加 熱したときに生ずる三酸化モリブデンの煙を煭着させる。このよ うにして得られた三酸化モリブデンは白色ないし淡黄色である が，原子状酸素によって多分次式のように深青色の低級酸化物に 变わる5)。

$$
3 \mathrm{MoO}_{3}+\mathrm{O}=\mathrm{Mo}_{3} \mathrm{O}_{3}+\mathrm{O}_{2}
$$

ところが放電した酸素ガスで酸素原子を多量に含んだものを青 色酸化モリブデンにあてると酸化されてふたたび淡黄白色にもど る。

\section{3 実 験 装 置}

装置の主要部を図 1 に示少。反応管 V は直径 $35 \mathrm{~mm}$, 長さ 210 $\mathrm{mm}$ のガラス管に幅 $0.28 \mathrm{~mm}$, 厚さ $0.024 \mathrm{~mm}$, 長さ $363 \mathrm{~mm}$ の白金リボンを封入したもので，白金リボンに直接電流を通じて 加熱する。白金りボンの温度はその電気抵抗から求める。この反 応管は径 $35 \mathrm{~mm}$, 長さ $35 \mathrm{~mm}$ の側管によって酸素原子検出装 置につながっている。

原子状酸素はガラス板につけた三酸化モリブデンまたは銀板の 変伊によって検出した。これらは容易に取りかえられるようにす り合わせの内管の下端に図に示すように吊してある。白金りボン と三酸化モリブデン付ガラス板（または銀板）との最短距朔注約 $55 \mathrm{~mm}$ である。他が変わったかどうかを調べるためには上部の） 与り合わせを廻して見やすい仙置にもってくる。

銀板は厚さ $0.15 \mathrm{~mm}$, 縦 $15 \mathrm{~mm}$, 横 $10 \mathrm{~mm}$ のものである。 トラップ $T_{1}$ および $T_{2}$ はドライアイスで泠却する。

放電管は内径 $20 \mathrm{~mm}$, 全長 $2 \mathrm{~m}$ のガラス管をU字形に曲げ, アルミニウム製電㥛を封入したものである。容量 $300 \mathrm{~W}$ のネオ ントランスで放電する。放電管内の死は反忍管内の质にくらべて

5) W. H. Rodebush, W. A. Nichols, J. Am. Chem. Soc. 52, 3864 (1930). 


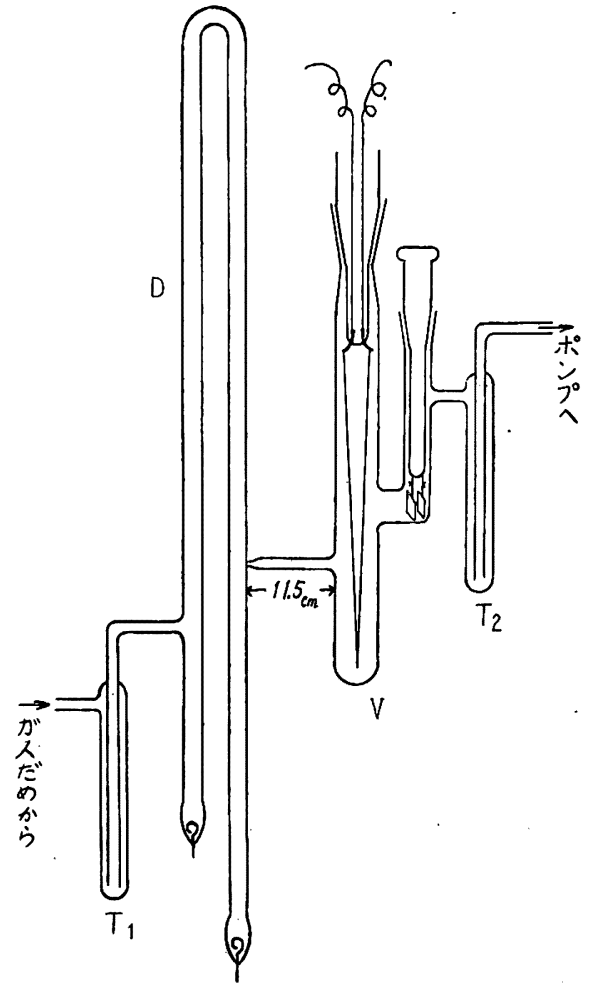

図 1 実験装置

相当高くし，反応管内はかなり低圧にたもちすみやかに排父でき るように放電管から反応管への出口は 局部的に 内径 $3 \mathrm{~mm}$ にし ぼってある。

\section{4 白金の規準状態}

後に詳述するように，放電した酸素で 1 度白金を処理すると， それ以後相当の時間真空中で白金リボンを加熱しても白金表面か ら原子状酸素が放出される。したがって，各実験ごとにあらかじ め白金線を完全にガス出しして原子状酸素が放出しない状態にす るのが理想的であるが，それは相当困難であり，ことにわれわ れの現在の装置では不可能に近い。したがって白金はなにかガス を含んでいたとしても原子状酸素を放出しないある一定の状態に し，すべての実験はその状態から出発することにした。この一定 の状態を規準状態と名づけることにする。

規準状態を得るにはつぎのようにする。まず装犆を十分排父し てから，水素を $5 \mathrm{mmHg}$ の压に満たし，白金リボンを $1100^{\circ} \mathrm{C}$ に 10 分間加熱し，つぎに排気しながら $1400^{\circ} \mathrm{C} に 1$ 時間熱する。 水素処理は白金に溶け込んだ酸素を除去するのが目的であるが， 装置内に三酸化モリブデンを入れるために $1 \mathrm{~atm}$ の空気を入れる と，白金に溶けた水素が酸素と反応して原子状水素または原子状 酸素が生成されるとみえ，後で熱したとき三酸化モリブデンが青 変することがある。それで水素処理が終ったのもトラップのドラ イアイスを除いて約 $1 \mathrm{mmHg}$ の空気または酸素を導入し，白金 リボンを $1100^{\circ} \mathrm{C}$ に 10 分間熱し，排気しながら $1400^{\circ} \mathrm{C}$ に 1 時 間加熱し，トラップをドライアイスで冷却する。このようにして 得られた規準状態では，真空中で白金線を $1400^{\circ} \mathrm{C} に 30$ 分間熱 しても三酸化モリブデンはほとんど変色しない。なお，トラップ $\mathrm{T}_{1}$ および $\mathrm{T}_{2}$ をドライアイスで冷却せずにヒックマン油拡散ポ ンプで装置を排気しながら白金りボンを $1400^{\circ} \mathrm{C}$ に 30 分間加熱 したら三酸化モりブデンが青变した。銀は变色しなかっったこれ
は油やグリースの蒸気が高温の白金表面に触れて分解し，水素原 子または有機の自由基が生成したためであろう。トラップをドラ イアイスで泠却すれば三酸化モリブデンは同一条件でほとんど変 色しない。

\section{5 実 験 結 果}

まず放電しながら酸素ガスを流して三酸化モリブデンの変色を 徵察した。反応管内の王が 0.04〜0.006 mmHg になるように酸 䊝を流していると三酸化モリブデンは深青色に変わる。変色のは やさはこの圧の範囲では压の大きいほど大である。ところが 0.1 〜 $1 \mathrm{mmHg}$ の压になるように多量の酸素を流すといったん青変 した酸化モリブデンはふたたび酸化されて淡黄白色にもどる。

以上の実験条件のもとでは，放電管からでてきた気相中の活性 物質はほとんど全部基底状態にある酸素原子で，準安定状態にあ る酸素の原子や分子およびオゾンはたとえ存在しても微量であ る6)。

以上の実験では乾操した酸素を用いたが，水蒸気を含んだ酸素 の方が器壁における酸素原子の再結合が減少し, 高浱度の酸素原 子を得ることができるといわれている。われわれも酸素に 2〜3 \%の水蒸気を混ぜて放電を試みたところ，銀板も短時間で真黒に なったが，不純物の混入をさけるため，以後の実験を乾操した酸 素でやることにした。

上に述べたように，反応管内の压が $0.1 〜 1 \mathrm{mmHg}$ 程度にな るような状態で放電ガスを反応管に約 20 分通じたのち，放電を やめて，装置内を十分排気した。放電ガスを流しているとき白金 リボンの電気抵抗をホイートストン橋によって測定したところ， 室温あるいはそれより数度高い温度に相当する抵抗値を示した。 この程度の圧のもとでは酸化モリブデンは淡黄色になっているか ら，引きつづいて排気しながら白金リボンを $1400^{\circ} \mathrm{C} に 20$ 分加 熱したところ深青色に変化した。

以上のような実験をくり返し実施しているうちに，次第に反応 管壁に黒褐色の物質が蒸着して来た。これを塩酸で処理したとこ ろ, 大部分溶解したので，白金の蒸着膜でなく，二酸化白金であ ろうと推定される。

\section{6 考察}

放電した酸港を白金リボンにあてると，放電によって生じた酸 素原子が白金表面に吸着し，あるいは白金内部へ溶解すると考え られる。したがって放電を止め，装置内を排気したのち，白金り ボンを加熱すると表面に吸着していた酸萃原子あるいは内部に溶 け込んでいた酸素原子が放出されることがあり得るであろう。し かし，もしそうならば活性化吸着した酸素も同様に白金表面から 原子状で放出されそうに思われる。Langmuir? によれば清浄な 白金表面に衝突した酸素分子はすべて原子に解離して吸着する。 これらの吸着原子は白金内部にも溶け込んでいるであろう。とこ ろが規準状態の項で述べたように， $1 \mathrm{mmHg}$ の酸素中で白金り ボンを熱し，排気したのち真空中で高温に加熱しても原子状酸素 の放出は認められない。活性化吸着した酸素は白金表面で原子に 解離していても，脱着するときには再結合して分子状になり，原 子状で放出されることはないと考えられる。

6) P. Harteck, U. Kopsch, Z. phys. Chem. B 12, 327 (1931),

7) I. Langmuir, Trans. Faraday Sọ. 17, 621 (1922), 
さて,白金は高温で酸素を活性化吸着したり,溶かし込んだりす るが8)9，また酸化もすることが知られている。白金海綿または白 金ハクは酸素中で約 $450^{\circ} \mathrm{C}$ に熱寸ると表面に一酸化白金（PtO） が生ずるといわれている10)。

Rideal ら ${ }^{11)}$ は $10^{-1} \sim 10^{-3} \mathrm{mmHg}$ 程度の酸素中で白金線を $1400^{\circ} \sim 1900^{\circ} \mathrm{K}$ に熱していると二酸化白金 $\left(\mathrm{PtO}_{2}\right)$ と考えられ る褐色の物質が器壁に沈着寸ることを認めた。この反応の速度は

$$
-\frac{d p}{d t}=a+b p \quad \text { ここにpは酸素圧 }
$$

で表わされる。右辺第 1 項は蒸発した白金原子が気相中で酸素と 結合して二酸化白金 $\left(\mathrm{PtO}_{2}\right)$ となり管壁に沈着する反応で，その 速度は酸素の圧が比較的大きいときは酸素の圧に無関係で 0 次反 応を呈する。第 2 項は白金表面で二酸化白金 $\left(\mathrm{PtO}_{2}\right)$ が生成し, これが蒸発して器壁に 沈着する反応で，その速度は圧に比例す

8) H. Reishauer, Z. phys. Chem. B 26, 399 (1934).

9）佐々木, 平木, 日化 61, 419 (1940).

10) J. N. Friend, "A Text-boox of Inorganic Chemistry" p. 303 vol. IX. part I. (1920).

11) E. K. Rideal, O. H. Wansbrough-Jones, Proc. Roy. Soc. A 123, 202 (1929)
る。最近 Fryburg(12) は放電で原子状酸秦を含む酸素をつくり， $1000^{\circ} \mathrm{C}$ の白金りボンにあてたところ，普通の酸絜によるよりも 白金の酸化が增進されることを見いだした。すなわち白金が $800^{\circ}$ C 以上のときは白金の酸化物はただちに蒸発し，周囲の管壁に褐 色の膜となって沈着する。この物質が二酸化白金 $\left(\mathrm{PtO}_{2}\right)$ である ことは電子回折で確かめられている。実験の結果, 白金の酸化に 対し，酸素原子甠酸素分子よりも 400～600 倍も反応しや寸いこ とがわかった。

上記のわれわれの实験においても，放電した酸素を白金りボン にあてると Fryburg の実験のように二酸化白金が容易に生じ,わ れわれの場合は白金リボンが常温であるため二酸化白金は白金表 面に蓄積し，後で加熱したとき分解して原子状酸素を放出するも のと考えられる。われわれの場合も実験をくり返しているうちに 二酸化白金と思われる黑褐色の物質が反応管壁に蒸着してきた。

終りに本研究に対し終始御愁篤なる御指導を睗わった三谷一雄 教授に厚く感謝の意を表する。

(1959 年 4 月, 日本化学会第 12 年会発表)

12) G. C. Fryburg, J. Chem. Phys. 24, 175 (1956).

\title{
低級イオウ酸素酸塭類の自己酸化反応に関する研究 （第 $4 ＼mathrm{~ 5 ~ 報 ） ~}$
}

\author{
（昭和 35 年 7 月 25 日受理）
}

岡部泰二郎・真 田寿朗・堀省一朗・大和久睦夫†

\section{（第 4 報） 低級イオウ酸素酸アルミニウムの自己酸化}

\author{
（岡部泰二郎·真田 寿朗・堀 省一朗）
}

\begin{abstract}
低級イオウ酸素酸塩類の自己酸化反応についての研究の一環として，(1) 塩基性硫酸アルミニウム溶液に亜硫酸ガスを飽和させ

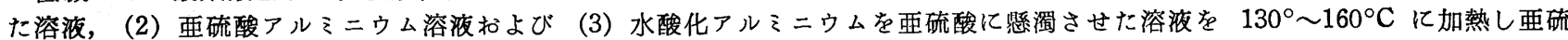
酸アルミニウムの自己酸化反応をしらべた。亜硫酸根の自己酸化反応はあらかじめ少量のイオウまたはチ才硫酸塩を添加するてと により促進されて多量のイオウと硫酸根を生成するが，その効果は後者の方が大である。上記溶液を $100^{\circ} \mathrm{C}$ 亿加熱すると無定型 の塩基性亜硫酸アル $ミ$ ウムが析出するが， $130^{\circ} \mathrm{C}$ 以上に加熱すると（1）および（3）の溶液では組成が $3 \mathrm{Al}_{2} \mathrm{O}_{3} \cdot 4 \mathrm{SO}_{3} \cdot x \mathrm{H}_{2} \mathrm{O}$ $(x=11 \sim 15)$ 飞相当する強酸に難溶性の白色观殿が析出し，(2) の溶液では組成が $2 \mathrm{Al}_{2} \mathrm{O}_{3} \cdot \mathrm{SO}_{3} \cdot x \mathrm{H}_{2} \mathrm{O}(x=11 \sim 12)$ に相当する溰 塩酸易溶の白色沈殿が析出した。両者と方顕微鏡観察およびX 線回折により区別できる明膫な結晶質である。
\end{abstract}

\section{1 緒言}

前報1にたいて 2 価金属のマグネシウムおよび亚鉛の低級イオ ウ酸素酸塩の自己酸化反応につき報告したが，今回 3 洒金属で工 業的にイオウ酸素酸々密接な関係をもつアルミニウムにつき研究 を行なった。彷来アルミニウム低級イオウ酸素酸塩が工業上利用 された例としては，1）塭基性硫酸アルミニウム溶液による亜硫 酸ガスの吸収浱縮法2), すなわち $\mathrm{Al}_{2} \mathrm{O}_{3} 10 \mathrm{~g} / 100 \mathrm{cc}$ 溶液, $\mathrm{Al}_{2} \mathrm{O}_{3}$ / $\mathrm{SO}_{4}{ }^{2-}$ モル比 $=10 / 16$ 程度の溶液を用いて比較的希薄な亜硫酸ガ スを吸収させて $\mathrm{SO}_{2}$ 濃度 $55 \sim 65 \mathrm{~g} / l$ の溶液とし，これを加熱 して濃厚垔硫酸ガスを回収する方法，2）互硫酸法アルミナ製造

†東北大学工学部応用化学科, 仙台市片平丁

1) 岡彩, 大稔, 场, 工化 61, 662 (1958); 阙部, 神沢, 堸, 日化 81, 529 (1960).

2）三菱金風鉱業，日特 74,695 (1927)；80,789，87,280 (1929) および M. P. Applebey, J. Soc. Chem. Ind. 58, 139 (1937)（外困では ICI Process といわれている).
法3)，すなわちアルミニウム含有鉱物を亜硫酸で処理してアルミ ニウムを抽出し，この抽出液を $80^{\circ} \sim 100^{\circ} \mathrm{C}$ に加熱して塭基性业 硫酸アルミニウムを沈殿させ，さらにこれを加熱分解してアルる ナを得る方法がある。これらの工業的諸法は約 $100^{\circ} \mathrm{C}$ 以下の操作 温度であって亚硫酸根の自己酸化反応はほとえど生起しないが, 本研究はアルミニウムイオンを共存寸る種々の組成の亜硫酸溶液 を耐压器中で $130^{\circ} \sim 160^{\circ} \mathrm{C}$, 加圧下で自己酸化反応を行なわせ, その反応速度, 添加物の影響, 生成沈殿の組成などについて研究 したものである。

\section{2 実験}

\section{1 装 置}

自己酸化反応に用いた装置は前報のものと同一である。

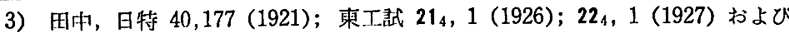
D. P. 579,487 (1932); 709,666 (1941); 726,133 (1942) (Goldschmidt 法といわれる)。 